\title{
THE INTERACTION OF SURFACTANTS WITH PLASTIC AND COPPER PLUMBING MATERIALS DURING DECONTAMINATION
}

Karen S. Casteloes ${ }^{a}$, Gamini P. Mendis $^{b}$, Holly K. Avins ${ }^{c}$, John A. Howarter $^{d}$, Andrew J. Whelton $^{e}$

a. Lyles School of Civil Engineering, 550 Stadium Mall Drive, Purdue University, West Lafayette, IN USA 47907; kcasteloes@ purdue.edu

b. School of Materials Engineering, 701 W. Stadium Avenue, West Lafayette, IN USA 47907; gmendis@ purdue.edu

c. School of Materials Engineering, 701 W. Stadium Avenue, West Lafayette, IN USA 47907; havins@purdue.edu

d. Division of Environmental and Ecological Engineering and School of Materials Engineering 701 W. Stadium Avenue, Purdue University, West Lafayette, IN USA 47907;

howarter@purdue.edu

e. Division of Environmental and Ecological Engineering and Lyles School of Civil Engineering, 550 Stadium Mall Drive, Purdue University, West Lafayette, IN USA 47907;

awhelton@purdue.edu

Corresponding Author: Andrew J. Whelton, Assistant Professor, Division of Environmental and

Ecological Engineering and Lyles School of Civil Engineering, 550 Stadium Mall Drive, Purdue University, West Lafayette, IN USA 47907; awhelton@purdue.edu 


\section{Abstract}

The study goal was to examine the effectiveness of surfactants to decontaminate plastic and copper potable water plumbing components. Several common potable water pipe and gasket plastics were examined as well as Alconox ${ }^{\circledR}$ detergent, Dawn ${ }^{\circledR}$ soap, and MAGIT-DG 100 surfactants. Results showed that the MAGIT-DG 100 solutions permeated all plastics within 3 days, effectively compromising tensile strength $(-82 \%)$, physical dimension $(+43 \%$ volume, $+45 \%$ weight), and oxidative resistance (-15\%). A variety of MAGIT-DG 100 solution compounds permeated plastic samples, not just the declared major ingredient. PVC and cPVC pipes sorbed the least amount of this solution's components of all the plastic pipes tested. Alconox ${ }^{\circledR}$ and Dawn ${ }^{\circledR}$ solutions caused minimal changes to the physical and mechanical properties of all plastics examined. Crosslinked polyethylene type A (PEX-a) pipe was more susceptible to crude oil contamination than copper pipe. Flushing with a pure water Alconox ${ }^{\circledR}$ solution mixture removed all benzene, toluene, ethylbenzene, and total xylenes (BTEX) from copper pipe. No decontamination method affected BTEX removal from PEX pipe. Under certain conditions surfactant solutions have the potential to alter material integrity and may not be a viable option in removing hydrophobic organic compounds from plastic pipe.

\section{Keywords}

Chemicals; Drinking water; Infrastructure; Decontamination; Surfactant; Plastic 


\subsection{Introduction}

Safe drinking water is an important health, safety, and economic security issue for communities worldwide. Since 2014, several large-scale drinking water contamination incidents in the U.S. and Canada have resulted in the chemical contamination of premise drinking water plumbing. Premise plumbing includes the service line as well as all pipes, tanks, appearances within the building. In the U.S. and Canada water bans have been issued to more than 1,000,000 people $^{1}$. In all cases, contaminated drinking water was distributed into building plumbing and this water contained chemicals many of which included organics such as diesel fuel, algal toxins, crude oil, or coal washing constituents. In some cases, the population was directed to limit water use for up to nine days while responders investigated the extent of contamination, devised procedures and ordered the population to clean out their plumbing infrastructure. Rapid and thorough removal of the contaminants from premise plumbing is critically important to return the infrastructure to safe use. If potable water is unavailable in residential or commercial buildings, hygiene and sanitation activities can be significantly limited, fire-suppression capability can be diminished, and commerce can be impacted. In recent years, this lack of water infrastructure decontamination knowledge has been recognized. ${ }^{2}$

A recent literature review revealed that there remains limited understanding about the effectiveness of premise plumbing decontamination approaches that have been used in the past. ${ }^{1}$ In the 2015 critical review, 39 drinking water pipe network organic chemical contamination incidents were found. When the specific decontamination action was reported, tap water flushing was used in 22 incidents ${ }^{1}$. Of those incidents, the flushing process was unable to achieve acceptable chemical concentrations for three incidents, two involved pesticide contamination. This difficulty prompted the removal and replacement of all contaminated plumbing 
infrastructure, especially those that contained plastics. ${ }^{1}$ Conditions requiring water infrastructure replacement are undesirable because of financial and time costs as well as inconvenience to the population affected. There is evidence that plastic premise plumbing components such as pipes, gaskets, and water heater dip tubes are especially susceptible to organic contaminant sorption. ${ }^{3-}$ ${ }^{5,6-10}$ In one bench-scale study, polyvinyl chloride (PVC) potable water pipes were contaminated with diesel fuel and could not be subsequently decontaminated by flushing. ${ }^{5}$ In another incident, after pesticide backflow occurred in a water distribution system, some affected plumbing systems were replaced. ${ }^{11}$ Another study found that crosslinked polyethylene (PEX-a) type A pipes sorbed a much greater mass of benzene, toluene, ethyl benzene, and xylene contaminants compared to PEX type B (PEX-b) pipes; Even after pipe flushing and 30 days of simulated water use, BTEX still leached from PEX pipes. ${ }^{12}$ Plastics in premise plumbing pose a unique decontamination challenge, and similar difficulty has been reported for cleaning contaminated ground water sampling materials such as PVC, polytetrafluroethylene (PTFE), polyethylene (PE), and polypropylene (PP). ${ }^{13,14}$ Unlike a contaminated plastic bottle or tube used for well water sampling however, removing and discarding an entire plastic building plumbing system is not trivial.

Surfactants may be helpful in decontaminating plastic plumbing components in-situ, but there is limited data available about their effectiveness for premise plumbing (Table 1). Surfactants reduce surface tension between the material-water interface by the hydrophobic component of the surfactant attaching to the hydrophobic material (such as the desired organic compound to be removed) while the hydrophilic component is able to interact favorably with water (or other hydrophilic materials). ${ }^{15,16}$ Surfactants can be nonionic, cationic, and/or anionic. Bench-scale experiments have shown that a 5\% Surfonic TDA-6 solution followed by a 10 
minute flush was capable of removing diesel fuel (78\%) and chlordane (99\%) from a PVC water pipe used for buried water distribution. ${ }^{17}$ Another bench-scale study found that a nonionic surfactant Surfonic N-60 solution removed chlordane (90\%) from cement piping. ${ }^{18}$ Following a diesel fuel water contamination incident in Israel, a PL-4 surfactant solution was able to decontaminate affected buried water distribution pipes, but information such as the type of piping, exposure duration, flow rate, and surfactant concentration were not reported. ${ }^{19}$ Unfortunately, water main studies are not directly applicable to premise plumbing. Premises have smaller diameter pipes, lower flowrates, and can have longer stagnation times, higher water temperatures, and a wider array of plastic components. Dawn ${ }^{\circledR}$ Ultra Dishwashing Liquid has been used to treat plumbing pipes contaminated with an unidentified oil ${ }^{20}$, but no performance data was found. This product has been frequently used to remove oil from aquatic animals after oil spills. Alconox ${ }^{\circledR}$ solutions have been used for potable water plumbing cleaning ${ }^{21}$ and to decontaminate tools and sampling equipment. ${ }^{22}$ Following polychlorinated biphenyl (PCB) contamination of a wastewater treatment plant in North Carolina, the surfactant MAG IT DG 100 was used for concrete basin decontamination. ${ }^{23}$ Surfactants previously studied or used by others have a wide range of compositions and properties (Table 2).

A review of the surfactant literature indicated that the interactions between surfactant solutions and plastics is lacking. In particular, nearly all of the prior water infrastructure decontamination studies focused on characterizing the water for the contaminant(s). No studies were found that examined the impact of the cleaning process on the integrity of the plastic plumbing component: dimensions, weight, mechanical strength, or subsequent ability to resist chemical attack/oxidation. It is well-known that some plastics can undergo swelling, resulting in dimensional changes and weight gain. For example, the elastomer ethylene propylene diene 
monomer (EPDM), commonly present as a gasket in fixtures, is susceptible to swelling under a wide range of solution conditions. ${ }^{24}$ The solubility parameter $(\delta)$ can be used to estimate the affinity for the plastic and any given chemical to interact (which dictates swelling and dissolution). Also important are the impacts of a cleaning process on the plastic's ability to maintain its strength and withstand operating conditions (i.e., pressure, temperature), along with the degree to which product service-life is affected. Popular premise plumbing plastic pipes include PEX pipes and high-density polyethylene (HDPE) pipes. These materials are manufactured to contain antioxidants that protect the polymer from chemical attack during routine use. The oxidative induction time (OIT) of these materials reflects the material's ability to resist oxidation. As the pipe's OIT value decreases, the plastic is less resistant to aging and undergoes polymer chain scission and further oxidation. ${ }^{25}$ Data is lacking on the degree to which surfactants enable water to permeate into plastics and reduce interfacial energies between plastics and waters.

This study was initiated to understand surfactant use for premise plumbing decontamination. ${ }^{26}$ The project goal was to better understand surfactant solution interactions with common premise plumbing plastics and to measure the ability of surfactants to clean plastic pipes contaminated by a crude oil-water solution. The specific research objectives were to (1) determine the impact of surfactant exposure on the strength, dimension, and mass of EPDM, PEX, HDPE, and low-density polyethylene (LDPE) plastics, (2) examine the mass impacts for PVC and cPVC pipes, and (3) determine the effectiveness of Alconox ${ }^{\circledR}$ surfactant solution for decontaminating PEX-a and copper pipes exposed to crude oil contaminated water. 
Table 1: Surfactant solution use and effectiveness studies

\begin{tabular}{|c|c|c|c|c|c|c|c|c|}
\hline \multirow[b]{2}{*}{ Surfactant } & \multirow[b]{2}{*}{ Use } & \multirow[b]{2}{*}{$\begin{array}{l}\text { Material } \\
\text { (Size) }\end{array}$} & \multicolumn{2}{|c|}{ Contamination Process } & \multicolumn{4}{|c|}{ Decontamination Approach and Results } \\
\hline & & & $\begin{array}{c}\text { Contaminant } \\
\text { (Concentration) }\end{array}$ & $\begin{array}{l}\text { Duration of } \\
\text { Contamination } \\
\text { before Decon }\end{array}$ & $\begin{array}{l}\text { Surfactant } \\
\text { Concentration } \\
\text { (Exposure } \\
\text { duration) }\end{array}$ & $\begin{array}{c}\text { Flow } \\
\text { Condition }\end{array}$ & $\begin{array}{l}\text { Water } \\
\text { Type }\end{array}$ & $\begin{array}{l}\text { Reported } \\
\text { Removal }\end{array}$ \\
\hline & $\begin{array}{l}\text { Premise } \\
\text { plumbing }\end{array}$ & $\mathrm{nr}$ & $\mathrm{nr}$ & $\mathrm{nr}$ & $\begin{array}{l}10 \% \\
(\mathrm{nr})\end{array}$ & $\mathrm{nr}$ & Tap & $\mathrm{nr}$ \\
\hline $\begin{array}{l}\text { Alconox }^{\circledR} \\
- \\
\text { Liquinox }^{\circledR}\end{array}$ & $\begin{array}{l}\text { Ground water } \\
\text { sampling } \\
\text { devices }^{13}\end{array}$ & $\begin{array}{l}\text { PVC and } \\
\text { PTFE (2 } \\
\text { inch } \\
\text { diam. } \\
\text { casing) }\end{array}$ & $\begin{array}{c}\text { Pesticides: } \\
\text { Lindane (645 } \\
\mu \mathrm{g} / \mathrm{L}), \text { dieldrin } \\
(393 \mu \mathrm{g} / \mathrm{L}), \\
\text { heptachlor }(9.7 \\
\mu \mathrm{g} / \mathrm{L}), \text { and aldrin }\end{array}$ & $24 \mathrm{hr}$ & $\begin{array}{c}1 \% \\
(5 \mathrm{~min})\end{array}$ & $\begin{array}{l}\text { Stirring in } \\
\text { glass vial }\end{array}$ & DI & $30-73 \%$ \\
\hline Dawn $^{\circledR}$ & $\begin{array}{l}\text { Premise } \\
\text { plumbing }^{20}\end{array}$ & $\begin{array}{l}\text { PEX } \\
\text { pipe } \\
(\mathrm{nr})\end{array}$ & $\begin{array}{l}\text { Unidentified oil } \\
\qquad(\mathrm{nr})\end{array}$ & $\mathrm{nr}$ & $\mathrm{nr}$ & $\mathrm{nr}$ & Tap & $\mathrm{nr}$ \\
\hline $\begin{array}{l}\text { MAG IT } \\
\text { DG } 100\end{array}$ & $\begin{array}{l}\text { Wastewater } \\
\text { treatment } \\
\text { plant } \\
\text { infrastructure }^{23}\end{array}$ & $\begin{array}{l}\text { Concrete } \\
\text { basin } \\
\text { (nr) }\end{array}$ & $\begin{array}{c}\text { PCBs } \\
(26 \mathrm{mg} / \mathrm{L})\end{array}$ & $\mathrm{nr}$ & $\mathrm{nr}$ & $\mathrm{nr}$ & Tap & $\mathrm{nr}$ \\
\hline $\begin{array}{l}\text { Surfonic } \\
\text { TDA-6 }\end{array}$ & Bench-scale $^{17}$ & $\begin{array}{l}\text { PVC } \\
\text { pipe } \\
\text { (6 inch } \\
\text { diam.) }\end{array}$ & $\begin{array}{l}\text { Diesel fuel } \\
(10 \mathrm{mg} / \mathrm{L}), \\
\text { Chlordane } \\
(10 \mathrm{mg} / \mathrm{L})\end{array}$ & 2 days & $\begin{array}{c}5 \% \\
(24 \mathrm{hr})\end{array}$ & $\begin{array}{l}\text { Recirculation } \\
60 \text { gpm; } \\
\text { Flush } 210 \\
\text { gpm (uni- } \\
\text { directional) }\end{array}$ & Tap & $\begin{array}{c}78 \% \\
\text { diesel; } \\
99 \% \\
\text { chlordane }\end{array}$ \\
\hline $\begin{array}{l}\text { Surfonic } \\
\text { N-60 }\end{array}$ & Bench-scale ${ }^{18}$ & $\begin{array}{l}\text { Cement } \\
\text { pipe } \\
\text { (nr) }\end{array}$ & $\begin{array}{l}\text { Chlordane } \\
\text { (nr) }\end{array}$ & $\mathrm{nr}$ & $\mathrm{nr}$ & $\mathrm{nr}$ & $\mathrm{nr}$ & $90 \%$ \\
\hline PL-4 & $\begin{array}{l}\text { Buried water }^{19} \\
\text { distribution } \\
\text { pipes }\end{array}$ & $\mathrm{nr}$ & $\begin{array}{l}\text { Diesel fuel } \\
\quad(\mathrm{nr})\end{array}$ & $\mathrm{nr}$ & $\mathrm{nr}$ & $\mathrm{nr}$ & Tap & $\mathrm{nr}$ \\
\hline
\end{tabular}


$\mathrm{nr}=$ non report; DI = De-ionized water; Tap $=$ Tap water; gpm = gallons per minute Bench-scale indicates testing was only conducted in a laboratory not full-scale water system. 
Table 2: Composition and properties of surfactant products used in the field or lab for water infrastructure decontamination

\begin{tabular}{|c|c|c|c|c|}
\hline $\begin{array}{l}\text { Solution } \\
\text { (Prior Use) }\end{array}$ & Chemical & $\begin{array}{l}\text { Water Solubility } \\
\text { at } 20^{\circ} \mathrm{C}(\mathrm{mg} / \mathrm{L})\end{array}$ & $\begin{array}{l}\text { Log } \\
\mathbf{K}_{\mathbf{o w}}\end{array}$ & $\begin{array}{l}\delta \\
\left(\mathrm{cal}^{1 / 2} / \mathbf{m}^{3 / 2}\right)\end{array}$ \\
\hline \multirow{7}{*}{$\begin{array}{l}\text { Alconox }{ }^{\circledR} \text { - Liquinox } \\
\text { (Premise Plumbing) }\end{array}$} & Water $(40-60 \%)$ & na & na & na \\
\hline & $\begin{array}{l}\text { Sodium Alkylbenzene Sulfonate (10-20\%) } \\
\text { [anionic] }\end{array}$ & $\mathrm{nf}$ & $\mathrm{nf}$ & $\mathrm{nf}$ \\
\hline & Alcohol Ethoxylate (1-5\%) [nonionic] & $\mathrm{nf}$ & $\mathrm{nf}$ & $\mathrm{nf}$ \\
\hline & Coconut Diethanolamide (1-5\%) & Insoluble $(<1,000)$ & $\mathrm{nf}$ & $\mathrm{nf}$ \\
\hline & Sodium Xylene Sulphonate (2-7\%) & Miscible & -1.86 & $\mathrm{nf}$ \\
\hline & Tripotassium EDTA $(1-5 \%)$ & Miscible & -13.15 & $\mathrm{nf}$ \\
\hline & Amount unreported $0 \%$ & & & \\
\hline \multirow{3}{*}{$\begin{array}{l}\text { MAG-IT DG100 } \\
\text { (Wastewater basin) }\end{array}$} & Citrus Terpene ( $d$-limonene) $(80 \%)$ & 7.57 & 4.57 & 8.07 (nonpolar) \\
\hline & Non-Ionic Surfactant Blend (20\%) & nf & $\mathrm{nf}$ & nf \\
\hline & Amount unreported $20 \%$ & & & \\
\hline \multirow{4}{*}{$\begin{array}{l}\text { Dawn }^{\circledR} \\
\text { (Premise Plumbing) }\end{array}$} & Ethanol (1-5\%) & Miscible & -0.31 & 12.96 \\
\hline & Sodium Laureth/Lauryl Sulfate (10-30\%) [anionic] & Miscible & & $\mathrm{nf}$ \\
\hline & Alkyl Dimethyl Amine Oxide (3-7\%) & 30.35 & 3.69 & $\mathrm{nf}$ \\
\hline & Amount unreported $58-86 \%$ & & & \\
\hline $\begin{array}{l}\text { Surfonic TDA-6 } \\
\text { (Bench-scale) }\end{array}$ & $\begin{array}{l}\text { Isotridecanol, Ethoxylated (100\%) [nonionic] } \\
\text { Amount unreported 0\% }\end{array}$ & Miscible & $\mathrm{nf}$ & $\mathrm{nf}$ \\
\hline $\begin{array}{l}\text { Surfonic N-60 } \\
\text { (Bench-scale) }\end{array}$ & $\begin{array}{l}\text { Nonylphenol, Ethoxylated (100\%) [nonionic] } \\
\text { Amount unreported 0\% }\end{array}$ & Miscible & 3.59 & $8.3^{27}$ \\
\hline \multirow{5}{*}{$\begin{array}{l}\text { PL-4 } \\
\text { (Potable Water } \\
\text { Distribution) }\end{array}$} & Sodium Hydroxide (5-15\%) & Miscible & -3.88 & $\mathrm{nf}$ \\
\hline & Sodium Hypochlorite (1-5\%) & Miscible & -3.42 & $\mathrm{nf}$ \\
\hline & $\begin{array}{l}\text { 2-Phosphono, 1,2,4-Butanetricarboxilic Acid (1- } \\
5 \% \text { ) }\end{array}$ & Miscible & $\mathrm{nf}$ & $\mathrm{nf}$ \\
\hline & $\begin{array}{l}\text { Homopolymer of Acrylic Acid, Sodium Salts (1- } \\
5 \% \text { ) }\end{array}$ & $\mathrm{nf}$ & $\mathrm{nf}$ & $\mathrm{nf}$ \\
\hline & Amount unreported $70-92 \%$ & & & \\
\hline
\end{tabular}

na = not applicable; $\mathrm{nf}=$ not found; Chemicals shown were reported on product material safety data sheets; Bench-scale indicates testing was only conducted in a laboratory and not a full-scale water system. 


\subsection{Materials}

2.1 Specimens and chemicals. Plastic specimens were obtained from several suppliers. EPDM and LDPE were Food and Drug Administration-compliant weather-resistant EPDM rubber 40A durometer hardness, $0.3175 \mathrm{~cm}$ thick sheets and moisture-resistant LDPE $0.3175 \mathrm{~cm}$ sheets (McMaster-Carr; Elmherst, IL, USA). LDPE is not known to be present in U.S. premise plumbing, but in Europe LDPE has been used as a water distribution pipe since the 1930s. ${ }^{28}$ Plumbing pipes were obtained from a local building supply store and include $1.905 \mathrm{~cm}$ diameter copper, HDPE, PVC, and cPVC pipes. PEX pipe, created using medium density polyethylene (MDPE) resin, ${ }^{29}$ was purchased directly from the manufacturer. Several surfactants were also obtained: Dawn ${ }^{\circledR}$ Ultra Dishwashing Liquid, Alconox ${ }^{\circledR}$ Liquinox critical cleaning liquid detergent from Fisher-Scientific (Pittsburgh, PA, USA), and MAG IT DG 100 (MAG) supplied by MAG-IT, LLC (Simpsonville, SC, USA). Louisiana light sweet crude oil (LLSC) was obtained from a crude oil processing facility in Mobile, AL. Benzene, toluene, ethylbenzene and total xylenes (BTEX) (99\%, SKU-43728) and limonene (97\%, SKU-183164) analytical standards were purchased from Sigma Aldrich (St. Louis, MO, USA).

2.2 Material integrity experiments. 2.2.1 Immersion testing. Plastic mass and dimension changes due to water and surfactant solution exposure were monitored for 21 days. ${ }^{30}$ Materials were prepared using an ASTM D638-5 cutting die (ODC Tooling \& Molds, Waterloo, ON, CA), were rinsed with DI water, and were dried at room temperature on a bench top for 24 hours. Materials were dimensioned using a digimetric caliper (Mitutoyo, Aurora, IL, USA) and weighed with a Mettler Toledo MS204TS New Classic MS-TS Analytical Balance with precision $\pm 0.1 \mathrm{mg}$ and lowest mass $0.1 \mathrm{mg}$ (Mettler Toledo, Columbus, OH, USA). 
Immersion experiments were conducted by placing materials in $40 \mathrm{~mL}$ amber EPA vials and vials were filled with either $30 \mathrm{~mL}$ of synthetic tap water, $10 \%(100 \mathrm{~mL} / \mathrm{L})$ Alconox ${ }^{\circledR}$ solution, 10\% Dawn $^{\circledR}$ soap solution, or 25\% (250 mL/L) MAG IT DG 100 solution. Vials were sealed with polytetrafluoroethylene (PTFE) caps and stored in the dark at room temperature until removal for characterization. Alconox ${ }^{\circledR}$ and MAG surfactant solutions were created according to each manufacturer's highest recommended dosage. Dawn ${ }^{\circledR}$ solutions were modeled after the Alconox ${ }^{\circledR}$ concentrations. Synthetic tap water solution was used as a control and made by following the recipe outlined in Zhang et al. ${ }^{31}$, without the addition of natural organic matter and with an alkalinity of $56.8 \mathrm{mg} / \mathrm{L}$. Water $\mathrm{pH}$ was adjusted to a range of 6-7 using $\mathrm{HCl}$ and $\mathrm{NaOH}$. The same synthetic tap water solution was used throughout the experiment. Addition of Alconox ${ }^{\circledR}$ and Dawn ${ }^{\circledR}$ products to synthetic tap water did not alter $\mathrm{pH}$, but MAG addition caused a $\mathrm{pH}$ reduction to 6 . After $3,7,14$, and 21 days, the samples were removed from the solutions and rinsed with DI water (1 min), to simulate flushing. Samples were then patted dry with Kimwipes ${ }^{\circledR}$ before dimension and mass measurement. The change in specimen mass was determined where $M_{1}$ was the initial mass (g), $M_{2}$ was the mass (g) after immersion (Equation 1).

Mass Change $(\%)=\left(\frac{M_{2}-M_{1}}{M_{1}}\right) \times 100$

\subsubsection{Thermo-gravimetric analysis (TGA). Thermogravimetric analysis of EPDM and LDPE} samples was conducted using a TGA Q50 V20.13 (TA Instruments, New Castle, DE, USA) in accordance with standard methods. ${ }^{32}$ TGA was performed using nitrogen gas $(75 \mathrm{~mL} / \mathrm{min})$. Heating started at $50^{\circ} \mathrm{C}$ and was ramped at $10^{\circ} \mathrm{C} / \mathrm{min}$ to $560^{\circ} \mathrm{C}$. Samples were cooled to $300^{\circ} \mathrm{C}$, and held for $2 \mathrm{~min}$. Next, air was selected as the purge gas $(75 \mathrm{~mL} / \mathrm{min})$ and temperature was ramped from $300^{\circ} \mathrm{C}$ to $600^{\circ} \mathrm{C}$ at $10^{\circ} \mathrm{C} / \mathrm{min}$. 
2.2.3 Tensile analysis. Tensile analysis was performed with a Universal Testing Machine (MTS Systems Corporation, Eden Prairie, MN, USA) in air at room temperature. The crosshead speed was $15 \mathrm{~mm} / \mathrm{min}$ for LDPE and $30 \mathrm{~mm} / \mathrm{min}$ for EPDM. A $1000 \mathrm{~N}$ load cell was used.

2.2.4 Contact angle analysis. Contact angle was measured with a goniometer (Rame-hart instrument co., Succasunna, NJ, USA). A $4 \mu \mathrm{L}$ drop of DI water was deposited on the sample surface through a syringe. The drop image was stored by a camera using an image analysis system (DROPimage Advanced) to determine the contact angle $(\theta)$ from the shape of the droplet. The contact angles were measured at room temperature and in air. For each sample, the mean value was calculated from 10 measurements, with each measurement conducted in triplicate.

2.2.5 Oxidation Induction Time (OIT) analysis. OIT analysis of HDPE and PEX pipe samples was conducted using a DSC Q2000 (TA Instruments, New Castle, DE, USA). Heating was started at $50^{\circ} \mathrm{C}$ and was ramped at $10^{\circ} \mathrm{C} / \mathrm{min}$ from 50 to $200^{\circ} \mathrm{C}$ in nitrogen at $50 \mathrm{~mL} / \mathrm{min}$. Samples were then held isothermal for $5 \mathrm{~min}$. Next, oxygen was selected as the purge gas (50 $\mathrm{mL} / \mathrm{min}$ ). A tangent to the exotherm was drawn to estimate the OIT value in min. Three replicates were analyzed per plastic type.

\subsection{PEX and copper pipe contamination and decontamination experiments with crude oil.}

Before pipe contamination and decontamination experiments were conducted for copper and PEX pipes, all pipes were flushed with tap water for $10 \mathrm{~min}$. Next, pipes were shock chlorinated using $200 \mathrm{mg} / \mathrm{L}$ free chlorine for $3 \mathrm{hr}$ to simulate standard cleaning conditions after their installation. ${ }^{29}$ Crude oil solutions used for pipe contamination were created in accordance with Anderson et. al. and characterized using analytical methods described below. ${ }^{33}$ Figure SM-1 details each step of the pipe contamination and decontamination process. 
Newly cleaned copper and PEX pipes were contaminated by filling $2.5 \mathrm{ft}(0.762 \mathrm{~m})$ length pipe sections with crude oil solution and capping them with PTFE lined stoppers. Pipes were covered during the experiment to prevent light interaction. After 3 days, solutions were removed and analyzed by techniques described below. All pipes were then flushed for $3 \mathrm{~min}$ at $2.5 \mathrm{gpm}(9.5 \mathrm{~L} / \mathrm{min})$. This flow rate was within the range of typical fixture flow rates: $0.25 \mathrm{gpm}$ $(0.95 \mathrm{~L} / \mathrm{min})$ for low-flow fixtures to near $10 \mathrm{gpm}(37.9 \mathrm{~L} / \mathrm{min})$ for older, less efficient fixtures including tub spouts. ${ }^{34}$ Next, the $10 \%$ Alconox ${ }^{\circledR}$ surfactant solution was added and pipes remained static for $24 \mathrm{hr}^{21}$ At the same time the other pipes were filled with synthetic tap water. After $24 \mathrm{hr}$, all pipes were flushed for $7 \mathrm{~min}$ at $2.5 \mathrm{gpm}(9.5 \mathrm{~L} / \mathrm{min})$. Finally, all pipes were filled with synthetic tap water (no oil) and held static for $48 \mathrm{hr}$. After $48 \mathrm{hr}$, water was removed and chemically analyzed. The $2.5 \mathrm{gpm}(9.5 \mathrm{~L} / \mathrm{min})$ flushing rate is typical of residential fixtures. ${ }^{34}$ The effectiveness of each decontamination approach was determined by characterizing water for total organic carbon (TOC) concentration and benzene, toluene, ethylbenzene, and total xylene (BTEX) concentrations. Total BTEX levels were calculated by addition of the individual components. TOC concentration was determined using a Shimadzu TOC-LCPH total organic carbon analyzer in non-purgeable organic carbon (NPOC) mode. The instrument was calibrated from 0 to $10 \mathrm{mg} / \mathrm{L}$ using a potassium hydrogen phthalate standard and an $\mathrm{r}^{2}$ of 0.999 was achieved. The method detection limit (MDL) was $0.10 \mathrm{mg} / \mathrm{L}$ TOC. Water samples were injected in triplicate with a 0.10 standard deviation. ${ }^{35}$ A GCMS-TQ8040 (Shimadzu, Japan) was used for the detection and quantification of BTEX. The instrument contained an ion source temperature of $200^{\circ} \mathrm{C}$, and was operated in Q3 selected ion monitoring (SIM) mode. The helium gas flow rate was $1.5 \mathrm{~mL} / \mathrm{min}$ and the purge flow rate was $3 \mathrm{~mL} / \mathrm{min}$. Each sample $(10 \mathrm{~mL})$ was added to a 20 $\mathrm{mL}$ amber vial and incubated at $70^{\circ} \mathrm{C}$ for $10 \mathrm{~min}$. Samples were adsorbed onto a $100 \mu \mathrm{m}$ 
polydimethylsiloxane (PDMS), fused silica 23 gauge fiber and then injected onto a $30 \mathrm{~m}, 0.32$ i.d. ZB-WAX column (Phenomenex, Torrance, CA). The temperature was held at $45^{\circ} \mathrm{C}$ for 2 min, increased to $75^{\circ} \mathrm{C}$ at a rate of $5^{\circ} \mathrm{C} / \mathrm{min}$, held for $3 \mathrm{~min}$, and then raised to $150^{\circ} \mathrm{C}$ and held for 3 min. Calibration curves were made using the BTEX standard (99\%) from $0.5 \mu \mathrm{g} / \mathrm{L}$ to $2 \mathrm{mg} / \mathrm{L}$ $\left(r^{2}=0.99\right)$. The MDL was determined using the BTEX standard $(99 \%)$. MDLs were $0.51 \mu \mathrm{g} / \mathrm{L}$ for benzene, $0.55 \mu \mathrm{g} / \mathrm{L}$ for toluene, $0.46 \mu \mathrm{g} / \mathrm{L}$ for ethylbenzene, $1.43 \mu \mathrm{g} / \mathrm{L}$ for total xylenes, and $2.27 \mu \mathrm{g} / \mathrm{L}$ for total BTEX.

2.4 Statistical analysis. Multivariate analysis of variance (MANOVA) was conducted using NCSS software for the data to determine the significance of the trends with an $\alpha=0.05$ and a 95\% confidence interval. Each experiment had three replicates. Mean and standard deviation values were calculated and reported.

\subsection{Results and discussion}

3.1 Interaction of surfactants with plastic materials. Statistically significant changes in weight and dimension were observed for some, surfactant-plastic pairs; with the remaining surfactantplastic pairs showing no measurable difference. Exposure time and surfactant type influenced the observed mass of all materials $(p<0.05)$.". MAG solution exposure increased the mass of all plastics during the immersion study $(p<0.05)$. Within the first 3 days, MAG solution caused EPDM to gain the greatest mass $(\sim 45 \%)$ and volume ( 43\%), and this solution-plastic pair reached equilibrium fairly quickly (Figures 1 and SM-2). According to the manufacturer's product safety data sheet, the MAG surfactant contained $80 \% d$-limonene, a compound with a solubility parameter of $8.07 \mathrm{cal}^{1 / 2} / \mathrm{m}^{3 / 2}$ similar to those for the plastics studied $(8.02-8.31$ $\mathrm{cal}^{1 / 2} / \mathrm{m}^{3 / 2}$ ) (Table 3). Similar solubility parameters for plastics and solvents generally lead to greater diffusion and swelling coefficients for the plastics. $d$-Limonene has been previously 
found to swell EPDM, and caused $26 \%$ weight gain after 15 min exposure at $50{ }^{\circ} \mathrm{C} .{ }^{36}$ Follow-up testing in the present study by immersing EPDM in pure limonene (97\%) at room temperature indicated significant mass $(+86 \%)$ and dimension $(+111 \%)$ increase after 3 days. A previous study on EPDM gaskets and an unknown concentration of $d$-limonene showed $0.4-0.6 \%$ increase in weight after $12 \mathrm{hr}$ of exposure at $80^{\circ} \mathrm{C} .{ }^{37}$ Swelling phenomena could contribute to molecular structure alterations and plastic degradation in premise plumbing. ${ }^{38,39}$ 
Table 3: Premise plumbing materials, applications, and properties

\begin{tabular}{|c|c|c|c|}
\hline \multirow[b]{2}{*}{ Material } & \multirow[b]{2}{*}{ Application } & \multicolumn{2}{|l|}{ Properties } \\
\hline & & Crystallinity, \% & $\begin{array}{l}\delta \\
\left(\mathrm{cal}^{1 / 2} / \mathrm{m}^{3 / 2}\right)\end{array}$ \\
\hline EPDM & $\begin{array}{l}\text { Gaskets for water distribution networks and } \\
\text { premise plumbing in U.S. and Europe }\end{array}$ & $15-40^{40}$ & $8.0^{41}$ \\
\hline LDPE & $\begin{array}{l}\text { Water distribution pipes in Europe }{ }^{42} \text {; Irrigation } \\
\text { pipes }^{43}\end{array}$ & $55-70^{44}$ & 8.31 \\
\hline HDPE & $\begin{array}{l}\text { Water distribution and premise plumbing pipes } \\
\text { in U.S. and Europe (cold) }{ }^{45}\end{array}$ & $69-72^{46}$ & $8.02^{47}$ \\
\hline PEX & $\begin{array}{l}\text { Water distribution and premise plumbing pipes } \\
\text { in U.S. and Europe (hot/cold) })^{48}\end{array}$ & $61-71^{46}$ & $\mathrm{nr}$ \\
\hline PVC & $\begin{array}{l}\text { Water distribution and premise plumbing pipes } \\
\text { in U.S. (cold) }\end{array}$ & na & $9.5-9.7$ \\
\hline cPVC & $\begin{array}{l}\text { Water distribution and premise plumbing pipes } \\
\text { in U.S. (hot/cold) }\end{array}$ & na & $\mathrm{nr}$ \\
\hline
\end{tabular}

$\mathrm{nr}=$ not reported; $\delta=$ solubility parameter; na $=$ not applicable

MAG solution altered the mass and dimension of the PE materials, but much less than EPDM (Figure SM-2). The LDPE resin sheet gained $7.0 \pm 0.7 \%$ weight in 3 days while $8.0 \pm$ $2.0 \%$ weight gain was detected for PEX pipe (medium-density resin) and $3.0 \pm 0.2 \%$ weight gain was found for HDPE pipe (high-density resin). A comparison between dimension changes between PE materials was not possible because pipe samples were curved and observed swelling was not uniform. Others have found MAG solution's main ingredient $d$-limonene can permeate LDPE. ${ }^{49}$ HDPE pipe was the most crystalline material and was more resistant to permeation by the MAG solution components than the same size but lesser dense resin PEX pipe sample..$^{50,51}$

While no mass or volume changes were detected for any material exposed to Dawn ${ }^{\circledR}$ solutions, Alconox ${ }^{\circledR}$ solution exposure caused a $1.1 \pm 0.03 \%$ mass reduction for the EPDM resin sheet after 3 day exposure $(p<0.05)$. Alconox ${ }^{\circledR}$ solution exposure did not cause a detectable impact on the mass or volume for LDPE, HDPE, or PEX samples. Tap water exposure also had 
no effect on any of the plastics. In comparison to PE and EPDM specimens, PVC and cPVC pipes gained a slight amount of weight due to MAG solution exposure (Figure SM-3).

(a)
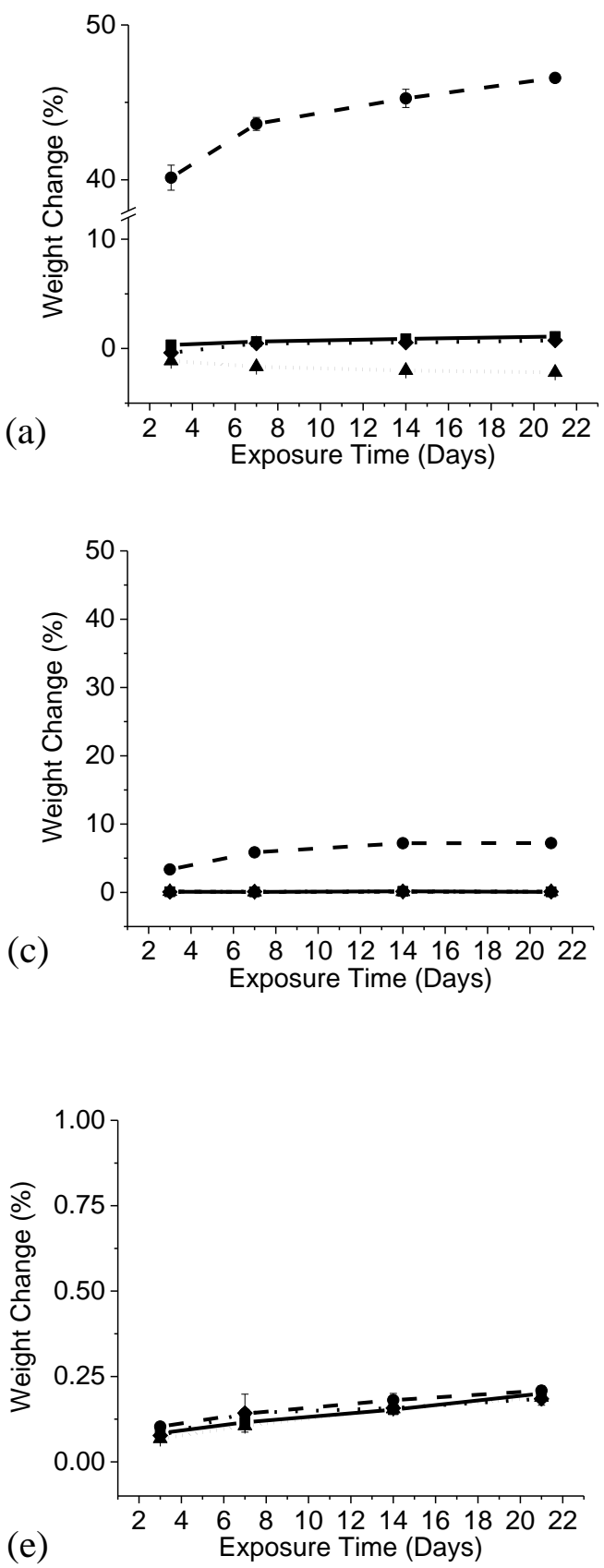

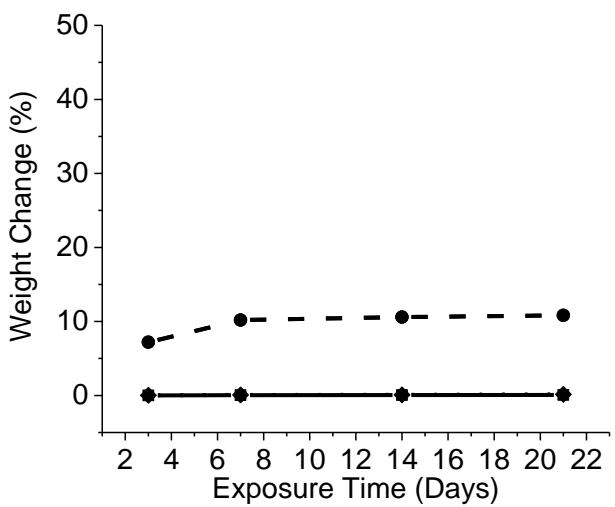

(d)
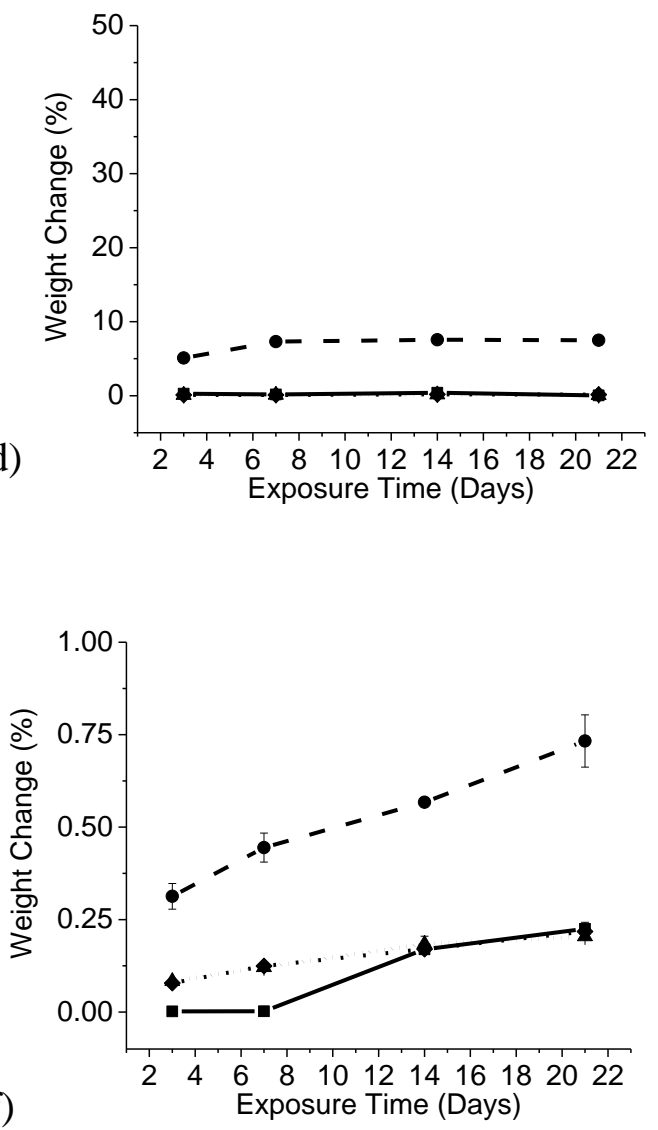

Figure 1: (a) LDPE, (b) EPDM, (c) HDPE pipe, (d) PEX (MDPE) pipe, (e) PVC pipe, and (f) cPVC pipe sample weight change as a function of exposure time. Results shown represent the mean and standard deviation of three replicates. Symbols represent Alconox (•), MAG (*), Dawn $(\mathbf{\Lambda})$, and Tap (ロ). 
TGA results for new EPDM and LDPE sheets represent classic thermograms, but the plastics exhibited significantly different thermograms after MAG solution exposure. The horizontal regions of the TGA thermograms were performed in oxygen and correspond to the amount of inorganic filler in the material. The materials contained $40 \%$ and $0 \%$ filler in the EPDM and LDPE samples, respectively. The thermogram for new EPDM exhibited multiple plateaus typical of the plastic blend. ${ }^{52,53}$ EPDM was significantly penetrated by MAG solution components and significant weight loss was detected between $50^{\circ} \mathrm{C}$ to $100^{\circ} \mathrm{C}(13.9 \%)$, from $100^{\circ} \mathrm{C}$ and $154^{\circ} \mathrm{C}(9.4 \%)$, and between $154^{\circ} \mathrm{C}$ to $176^{\circ} \mathrm{C}(1.5 \%)$ (Figure 2). For EPDM exposed to tap water there were no changes in weight loss at these temperatures. Because the boiling point of the MAG solution was $154^{\circ} \mathrm{C}$ and the boiling point of $d$-limonene (reportedly $80 \%$ of MAG) was $176^{\circ} \mathrm{C}$, the mass loss at temperatures lower than $176^{\circ} \mathrm{C}$ was likely due to the unreported ingredients in the manufacturer's product (Table 2) and water which can sorb into the plastic matrix in the presence of the active surfactants. TGA results indicate that unidentified surfactant compounds permeated into the plastic, volatilized during thermal analysis, and a low amount of water sorption occurred.

New LDPE was primarily resin as indicated by a weight loss of $4.8 \%$ and an onset degradation temperature of $416^{\circ} \mathrm{C}^{54,55}$ After MAG solution exposure, compounds volatilized from the LDPE sample, but the total mass loss was much less compared to EPDM. At $100^{\circ} \mathrm{C}$, approximately $2.0 \%$ weight loss was detected, while between $100^{\circ} \mathrm{C}$ and $154^{\circ} \mathrm{C} 3.9 \%$ loss was measured and then by $176^{\circ} \mathrm{C}$ another $0.7 \%$ loss was observed. The new LDPE and LDPE exposed to tap water had no changes in weight loss at these temperatures. The largest weight loss was between $100^{\circ} \mathrm{C}$ and $154^{\circ} \mathrm{C}$, indicating volatilization of the MAG solution from the plastic. Dawn $^{\circledR}$ and Alconox ${ }^{\circledR}$ solution exposure had no observable effect on thermogram results. 
Material surface wettability and mechanical strength properties were impacted by surfactant solution exposure. Both MAG and Alconox ${ }^{\circledR}$ solutions decreased the static water contact angle for EPDM, while only the MAG solution decreased the contact angle for LDPE. Surfactants can reduce the contact angle on hydrophobic surfaces ${ }^{56}$ by lowering the surface tension of the droplet and creating a more wettable surface. While contact angles for EPDM and LDPE changed after 3 days of exposure, further changes were not detected with respect to time $(p=0.075 ; p=0.096)$. However, each surfactant solution caused a different surface wettability response $(p<0.05)$ (Figure SM-4).
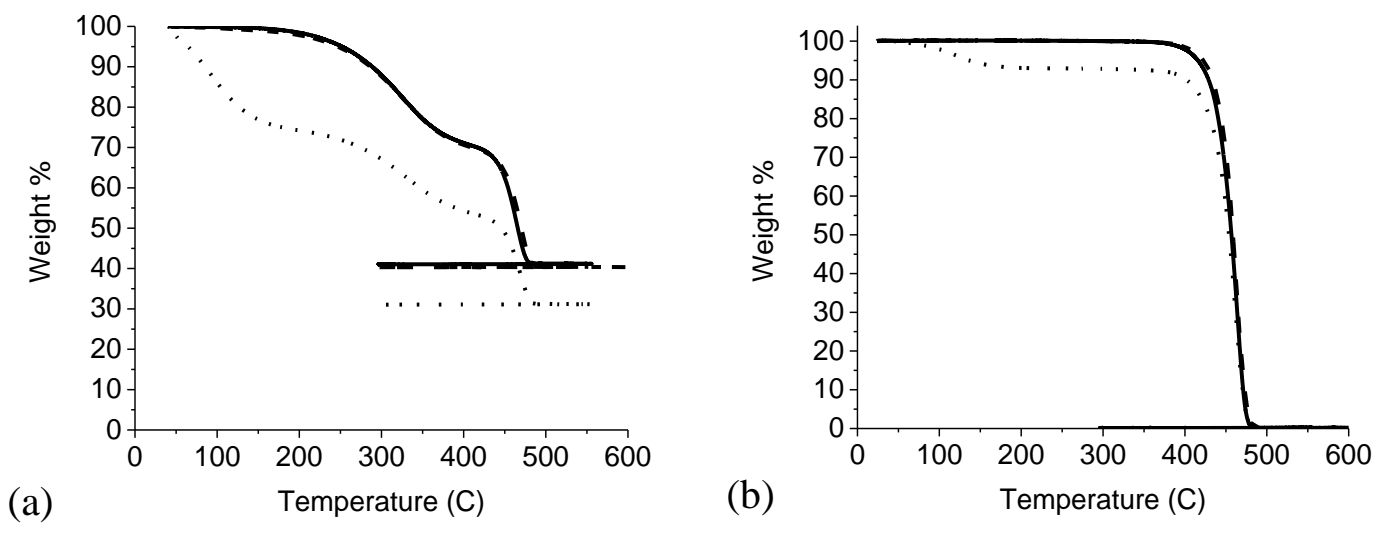

Figure 2: TGA curves for (a) EPDM and (b) LDPE following 3-day exposure to the MAG IT DG 100 solution and tap water. The blank is the new material. Selected sample run shown. Lines represent: - - Tap, $\cdots$ MAG, and - Blank.

MAG solution exposure caused a reduction in EPDM and LDPE mechanical properties, and reduced the ability of HDPE pipe to resist chemical oxidation. The MAG solution caused the greatest change in ultimate stress and reduced tensile strength (Table 4). Stress-strain diagrams for surfactant-plastic pairs can be found in Figures SM-5. Others have found that $d$-limonene sorption into LDPE film caused a reduction in specimen tensile strength. ${ }^{49}$ Observed changes in ultimate stress and tensile strength could be due to the swelling caused by MAG solution 
rendering the polymer network less able to absorb mechanical energy like unexposed polymers.

The finding that MAG solution exposure reduced the antioxidant content of HDPE pipe by

$15.4 \%$ is significant $(p<0.05)$ and implies decontamination approaches could reduce the service-

life of some installed plastics (Table 5). ${ }^{25}$ No changes to mechanical properties were found for

any materials exposed to Alconox ${ }^{\circledR}$ and $\operatorname{Dawn}^{\circledR}$ solutions. These surfactant solutions had no

detectable impact on the oxidative resistance of PEX-a pipe. Antioxidant analysis was not

conducted on LDPE or EPDM.

Table 4: Ultimate tensile strength (MPa) at $23^{\circ} \mathrm{C}$ for LDPE and EPDM exposed to the surfactant solutions

\begin{tabular}{lllll}
\hline $\begin{array}{l}\text { Material and } \\
\text { Exposure } \\
\text { Duration }\end{array}$ & $\begin{array}{l}\text { Solutions } \\
\text { Synthetic } \\
\text { Tap Water }\end{array}$ & Alconox® & MAG & Dawn $^{\circledR}$ \\
\hline $\boldsymbol{L D P E}$ & & & & \\
Day 3 & $16.27 \pm 0.96$ & $19.80 \pm 1.24$ & $10.89 \pm 0.84$ & $18.46 \pm 1.34$ \\
Day 7 & $20.80 \pm 0.92$ & $19.47 \pm 0.50$ & $11.02 \pm 0.74$ & $18.70 \pm 0.40$ \\
Day 14 & $18.68 \pm 2.37$ & $15.64 \pm 0.02$ & $11.00 \pm 0.21$ & $17.73 \pm 4.43$ \\
Day 21 & $21.18 \pm 2.01$ & $18.79 \pm 2.71$ & $12.01 \pm 0.25$ & $19.33 \pm 3.97$ \\
$\boldsymbol{E P D M}$ & & & & \\
Day 3 & nds & nds & $1.02 \pm 0.03$ & nds \\
Day 7 & $4.87 \pm 0.56$ & $5.42 \pm 0.26$ & $0.57 \pm 0.22$ & $5.23 \pm 0.71$ \\
Day 14 & $4.90 \pm 0.80$ & $5.92 \pm 0.36$ & $1.01 \pm 0.14$ & $6.31 \pm 0.63$ \\
Day 21 & $5.06 \pm 0.09$ & $5.74 \pm 0.37$ & $0.94 \pm 0.13$ & $6.14 \pm 0.66$ \\
\hline
\end{tabular}

Mean and standard deviation values shown of three replicates; nds = no data due to slippage; Tensile strength for samples not exposed to any solutions were 15.84 \pm 2.02 (LDPE) and $5.63 \pm 0.40$ (EPDM); Tensile strength reported by the manufacturer was 21.37 (LDPE) and 5.52 (EPDM)

Table 5: Oxidation induction time (min) for HDPE and PEX pipes that were exposed to various solutions for 3 days

\begin{tabular}{lll}
\hline Material & HDPE Pipe & PEX-a Pipe \\
\hline New pipe & $96.3 \pm 2.4$ & $40.0 \pm 0.5$ \\
\hline Solution & & \\
Tap water & $94.0 \pm 3.3$ & $30.8 \pm 5.9$ \\
Dawn ${ }^{\circledR}$ & $93.4 \pm 2.8$ & $42.0 \pm 3.3$ \\
Alconox ${ }^{\circledR}$ & $90.0 \pm 1.3$ & $48.7 \pm 20.7^{*}$ \\
MAG & $77.7 \pm 1.0$ & $41.9 \pm 8.6$ \\
\hline
\end{tabular}

Results shown represent the mean and standard deviation of three replicates; Initial OIT values for new pipes are similar to the literature ${ }^{46,57}$; OIT analysis was not conducted on EPDM and LDPE specimens or $\mathrm{PVC}$ and $\mathrm{cPVC}$ pipes because this test is used for polyethylene drinking water piping. ${ }^{*} \mathrm{n}=4$; additional 
replicate was run for PEX exposed to Alconox ${ }^{\circledR}$ because of high variability and additional replicate also showed high variability.

\subsection{Effectiveness of Alconox ${ }^{\circledR}$ for decontaminating PEX and copper pipes exposed to crude}

oil contaminated water. The Alconox ${ }^{\circledR}$ solution was chosen for further scrutiny because it has been reportedly used for premise plumbing decontamination. ${ }^{13,22,58}$ PEX-a pipe was selected for study because it was one of the most susceptible plastic pipes to crude oil permeation in a related study. Copper pipes were selected for evaluation because organic compounds cannot diffuse into their bulk. A crude oil contaminated water/pipe exposure period of 3 days was selected because this duration was within the range of past do not use drinking water orders. ${ }^{1}$

In preparation for this experiment, PEX-a pipes and copper pipes were exposed to crude oil contaminated water. The initial total BTEX aqueous concentration was about $5 \mathrm{mg} / \mathrm{L}$ and the exposure occurred for 3 days. Initial crude oil concentration was based on an ongoing study conducted by the EPA, which examined crude oil-water contamination of buried water distribution pipes. ${ }^{59}$ After 3 days, the total BTEX concentration in the crude oil contaminated water removed from copper pipe was about $48.5 \%$ less than its initial value. This implied BTEX compounds adhered to the pipe surface, diffused into the pipe, or were lost due to volatilization. After 3 days of contaminated water exposure to PEX-a pipe, the total BTEX concentration of water removed from the PEX-a pipe was $92.8 \%$ less than its initial concentration (Figure 3). Thus, a significant amount of the BTEX compounds sorbed onto and/or into the PEX pipe. Reductions for all individual BTEX components during this 3 day exposure period were statistically significant $(p<0.05)$. Sorption of crude oil compounds into plastic pipe has also been observed previously. ${ }^{3,7}$

Following the two different decontamination techniques evaluated (flushing and flushing with Alconox ${ }^{\circledR}$ surfactant solution), pipes were filled with clean synthetic tap water, capped with 
PTFE caps, and kept static for $48 \mathrm{hr}$. For copper pipe, because no BTEX was detected following the $48 \mathrm{hr}$ stagnation period, all of the BTEX compounds seem to have been removed by both decontamination processes. On the contrary, neither decontamination process resulted in similar BTEX removal effectiveness for PEX pipe. After $48 \mathrm{hr}$, the total BTEX levels for PEX pipe ranged from 2.2 to $7.1 \mu \mathrm{g} / \mathrm{L}$ (Figure 4, Table SM-1). Benzene, $9.9 \mu \mathrm{g} / \mathrm{L}$, exceeded its primary maximum contaminant level (MCL) of $5.5 \mu \mathrm{g} / \mathrm{L}^{8}$ but was below the odor $(2,000 \mu \mathrm{g} / \mathrm{L})$ and taste $(40 \mu \mathrm{g} / \mathrm{L})$ threshold concentrations (TTC, OTC) ${ }^{60}$ Toluene, ethylbenzene, and total xylene concentrations were found at levels below their respective MCLs, TTCs, and OTCs. TOC concentration was not a good indicator of chemical leaching by crude oil contaminated PEX pipes because PEX pipes (not exposed to crude oil) released $6.9 \mathrm{mg} / \mathrm{L}$ TOC after 3 days of stagnation. This observation is typical of PEX sold in the U.S. where the range of TOC have been reported from 1 to $7 \mathrm{mg} / \mathrm{L}$ depending on PEX brand, ${ }^{61}$ though only a few PEX pipe TOC leaching studies have been conducted to date.

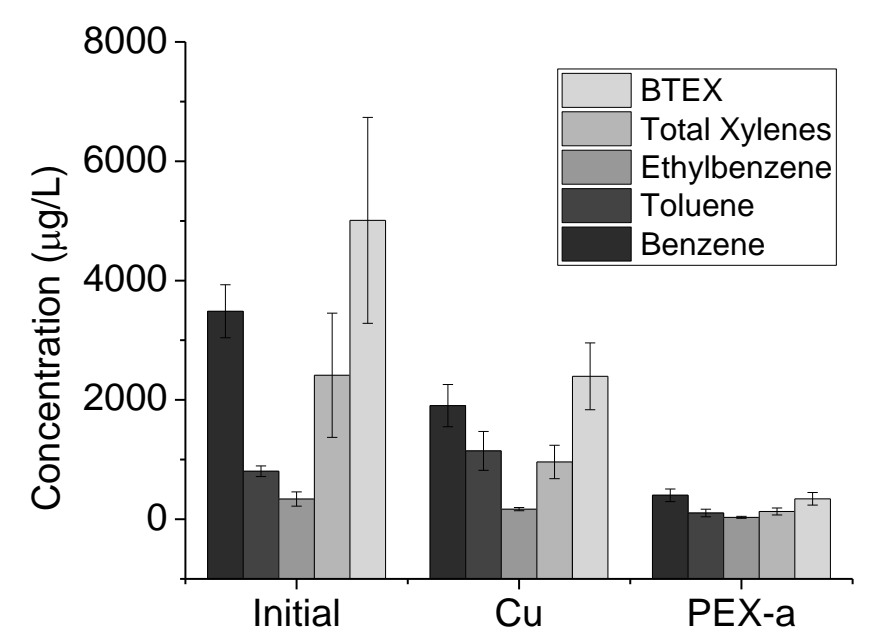

Figure 3: Concentration of total BTEX in water at $23^{\circ} \mathrm{C}$ after 3 day pipe exposure. 
In the present study, BTEX compounds could be readily removed from new copper pipe similar to others, ${ }^{13}$ but BTEX compounds permeated into the bulk PEX pipe and the decontamination methods applied were ineffective. This finding implies that removing hydrophobic compounds from premise plumbing plastics may be similar to challenges observed in other industries. For example, pesticides could not be removed from PVC and PTFE plastics used for environmental monitoring following a room-temperature water detergent wash (1\% Liquinox for 5 min, stirring). ${ }^{13}$ Chlorinated hydrocarbons could not be completely removed from PVC, PE, and PP tubing plastics used for environmental monitoring and these compounds had permeated into the plastic's bulk matrix. ${ }^{14}$ Results of the present study indicate that short-term exposure of plastic pipe to crude oil contaminated water allowed contaminants to diffuse into the plastic's bulk matrix and leaching occurred once the plastic was simulated to be placed back into service.

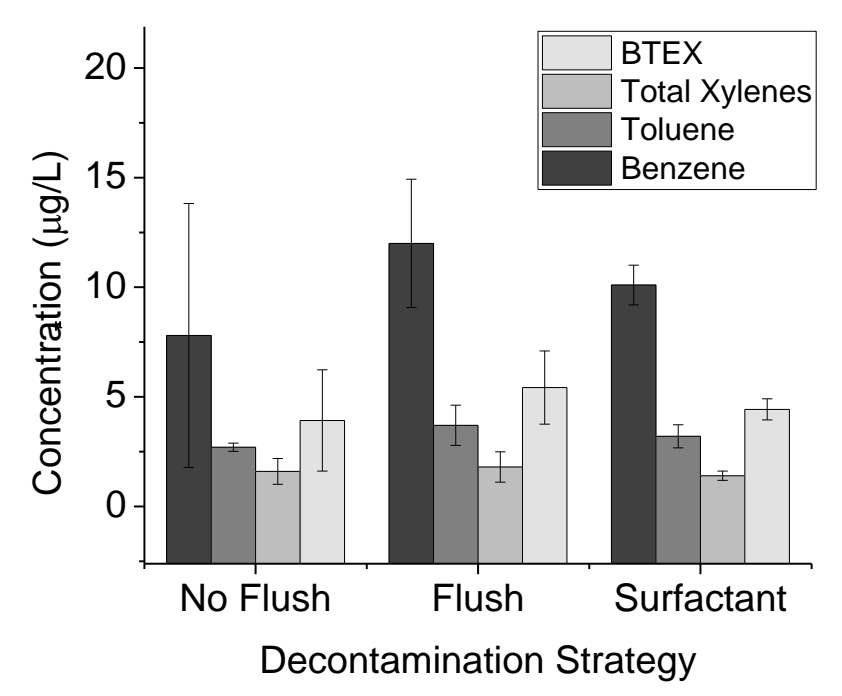

Figure 4: Total BTEX drinking water concentration after 48 hours of water contact with crude oil contaminated PEX-a pipe

3.3 Limitations and future work. Additional work is needed to identify procedures and technologies capable of rapidly returning plastic plumbing components to safe use after they 
have been contaminated. A limitation of the present work is that only one petroleum substance was evaluated and there is wide variability in organic chemical loadings in oils even across crude oils. Before crude oil contaminated water reaches the water distribution system or premise plumbing, it may also undergo chemical/physical treatment processes such as oxidation, sorption, and/or dilution. The crude oil mixing approach selected was based on work conducted by the U.S. EPA for iron and cement drinking water distribution pipe contamination by crude oil. Not examined in the present study was the fate of other contaminants such as radionuclides, semi-volatile organic compounds (SVOC), and metals, all known to be present in crude oils ${ }^{12}$ While the PEX pipe examined was comprised of MDPE resin and was less resistant to chemical permeation than HDPE pipe, additional premise plumbing product surfactant interaction and decontamination evaluations are needed (e.g., PVC, cPVC, and polypropylene). Different results are expected based on different plastics. For example, chemical permeation of PVC pipe has shown to not appreciably occur at room temperature unless activity exceeds $0.60 .{ }^{62}$ Additional work could be conducted to determine if this theory applies to higher water temperatures observed in premise plumbing $\left(60^{\circ} \mathrm{C}\right.$ domestic hot water, $80^{\circ} \mathrm{C}$ for some appliances), and to examine cPVC pipe. Shorter exposure durations could also be examined. Other elastomers not studied but also used in premise plumbing include Viton ${ }^{\circledR}$, butyl rubber, natural rubber, and styrene-butadiene-rubber, and may pose different decontamination challenges due to their varied chemical composition and structure. It is unknown if the age of the plastic may also influence its ability to be cleaned.

Further approaches to remove organic contaminants from plastics could involve hot water, air flushing, and organic solvent exposure. As results of this study show, the effect of the decontamination process on the plastic's mechanical integrity and its ability to resist oxidation 
should also be studied. In recent years, tens of thousands of premise plumbing systems have been contaminated with organic chemicals in large-scale water contamination incidents in the U.S. and Canada. Limited information exists about how to rapidly and safely decontaminate plumbing systems. While plastics are being increasingly installed because of their corrosion resistance and low cost, there is a need to better understand how to clean them in-situ so that removal and replacement is not necessary. This work is needed to help inform emergency responders how exposure time can influence a decision when plastic removal and replacement is required.

\subsection{Conclusion}

Following a large-scale drinking water contamination incident, in-situ decontamination of premise plumbing is preferred, but past incidents have revealed situations where removal and replacement of contaminated components has been necessary. The interactions between three surfactants and four different plastics were studied at room temperature. Results showed that MAG solution exposure caused the greatest changes to plastic integrity. MAG solution constituents, at room temperature, permeated all plastics within three days and EPDM was the most affected ( $+45 \%$ weight; $+43 \%$ volume; $-82 \%$ tensile strength). Thermogravimetric analysis showed MAG solution compounds with boiling points less than $100^{\circ} \mathrm{C}$ up to $176^{\circ} \mathrm{C}$ permeated both EPDM and LDPE samples and volatilized when the contaminated plastics were heated. MAG solutions caused a $15 \%$ reduction in the oxidative resistance of HDPE pipe indicating a loss of antioxidants, and thus a reduction in service-life. PVC and cPVC sorbed the least amount of MAG solution components of all the plastic pipes tested. Alconox ${ }^{\circledR}$ and Dawn ${ }^{\circledR}$ solutions caused minimal changes to the physical and mechanical properties of the plastics examined.

Water flushing and flushing with an Alconox ${ }^{\circledR}$ detergent solution removed BTEX from contaminated copper pipe. No statistically significant difference in BTEX concentration was 
found between the PEX pipe decontamination methods. After PEX pipe cleaning and a two day stagnation period, $9.9 \mu \mathrm{g} / \mathrm{L}$ of benzene was detected in the drinking water. This level exceeded the primary drinking water health limit of $5 \mu \mathrm{g} / \mathrm{L}$, but was below its odor and taste threshold limits. Toluene, ethylbenzene, and xylenes were detected in the two day stagnated water, but at levels lower than their drinking water health standards and odor thresholds. The $6.7 \mathrm{mg} / \mathrm{L}$ background TOC concentration caused by new PEX pipe inhibited use of this water quality parameter as a decontamination effectiveness indicator. Results of the present study indicate that BTEX compounds permeated into PEX pipe and the decontamination methods had no effect on PEX pipe leaching.

Results of the present study indicate that under certain conditions surfactant solutions have the potential to alter material integrity and may not be a viable option in removing hydrophobic organic compounds from plastic pipe. The extent to which these compounds can persist within premise plumbing materials and be rapidly removed should be further examined. A more extensive examination of surfactants is recommended as well as the examination of the role of water flow rate and elevated temperatures. Technologies and methods are needed to decontaminate premise plumbing in-situ and current knowledge is lacking.

\subsection{Acknowledgements}

This work was funded by a grant (1424627) from the U.S. National Science Foundation CBET program. Thanks are extended to Kyla Prendergast and Yufei Zhang at Purdue University for their assistance conducting experiments. The authors also appreciate Alconox ${ }^{\circledR}$ for its input and MAG-IT, LLC for providing a product sample.

\subsection{References}


1. Casteloes KS, Brazeau RH, Whelton AJ. Decontaminating chemically contaminated residential premise plumbing systems by flushing. Environmental Science: Water Research and Technology. 2015: 1, 787-799. DOI: 10.1039/C5EW00118H.

2. U.S. Environmental Protection Agency (EPA). 2015 U.S. Environmental Protection Agency (EPA) Decontamination Research and Development. 2015;(July):NC, USA.

3. American Water Works Association (AWWA), Economic and Engineering Services Inc. Permeation and Leaching. Prepared for USEPA. Washington D.C.; 2002. 24 p.

4. Holsen TM, Park JK, Jenkins D, Selleck RE. Contamination of Potable Water by Permeation of Plastic Pipe. Journal American Water Works Association. 1991;83(8):53-56.

5. Treado S, Watson S. Building Plumbing System Decontamination- First Report on Recommendations. Gaithersburg: National Institute of Standards and Technology; 2009. Gaithersburg, USA.

6. Mao F, Gaunt JA, Ong SK, Cheng C-L. Permeation of Petroleum-Based Hydrocarbons through PVC Pipe Joints with Rieber Gasket Systems. Journal of Environmental Engineering. 2011;137(12):1128-1135.

7. Mao F, Gaunt JA, Ong SK. Permeation of Petroleum-Based Aromatic Compounds Through Polyethylene Pipes Under Simulated Field Conditions. In: Proceedings of the AWWA Annual Conference and Exposition; 2006. p. 12.

8. Koo D-H. Development of a BTEX Permeation Calculator for High Density Polyethylene (HDPE) Water Pipe (ASCE). In: Proceedings of the ASCE Pipelines Conference, Reston, Va; 2013. http://ascelibrary.org/doi/abs/10.1061/9780784413012.075

9. Goodfellow F, Ouki SK, Murray V. Permeation of Organic Chemicals Through Plastic WaterSupply Pipes. Water and Environment Journal. 2002;16(2):85-89.

10. Müller JF, Manomanii K, Mortimer MR, McLachlan MS. Partitioning of polycyclic aromatic hydrocarbons in the polyethylene/water system. Journal of Analytical Chemistry. 2001;371(6):816-822.

11. Watts. Stop Backflow News: Case Histories and Solutions. North Andover, MA, USA; 1998. $60 \mathrm{p}$.

12. Huang X, Whelton AJ, Andry S, Yaputri J, Kelly D, Ladner DA. Interaction of Fracking and Crude Oil Contaminants with Water Distribution Pipes, EO 2014-07, Final Report. 2016. Water Research Foundation, Denver, CO USA.

13. Parker L V., Ranney TA. Decontaminating Materials Used in Ground Water Sampling Devices: Organic Contaminants. Groundwater Monitoring \& Remediation. 2000; 20, (1): 56-68.

14. Barcelona MJ, Helfrich JA, Garske EE. Sampling Tubing Effects on Groundwater Samples. Analytical Chemistry. 1985;57(2):460-464.

15. Haigh SD. A Review of the Interaction of Surfactants with Organic Contaminants in soil. Science of The Total Environment. 1996;185(1-3):161-170.

16. Yeom IT, Ghosh MM, Cox CD. Kinetic Aspects of Surfactant Solubilization of Soil-Bound Polycyclic Aromatic Hydrocarbons. Environmental Science \& Technology. 1996;30(5):1589-1595.

17. USEPA. Pilot-Scale Tests and Systems Evaluation for the Containment, Treatment, and Decontamination of Selected Materials from T\&E Building Pipe Loop Equipment. Cincinnati, OH. 2008;(January):88. 
18. Szabo J, Minamyer S. Decontamination of chemical agents from drinking water infrastructure: A literature review and summary. Environment International. 2014;72:119-123.

19. Sezra, S. (2014, December 23). Personal Communication.

20. Shine, T. (2015, September 29). Personal Communication.

21. McLaughlin, M. Use of surfactants to remediate premise plumbing. (2015, April 1). Personal Communication.

22. Mickam JT, Bellandi R, Tifft EC. Equipment Decontamination Procedures for Ground Water and Vadose Zone Monitoring Programs: Status and Prospects. Ground Water Monitoring \& Remediation. 1989;9(2):100-115.

23. Lamb, P. AFFF backflow into city water distribution system response and recovery. (2014, November 21). Personal Communication.

24. Somasundaran P, Krishnakumar S, Mehta SC. A new model to describe the sorption of surfactants on solids in non-aqueous media. Journal of Colloid and Interface Science. 2005;292:373-380.

25. Rockaway TD, Willing GA, Schreck RM, Davis KR. Performance of Elastomeric Components in Contact With Potable Water. AWWA; 2007. 336 p.

26. Comyn J. Polymer Permeability. Essex, England: Springer Science \& Business Media; 1985. $384 \mathrm{p}$.

27. Fox KR. Water Treatment and Equipment Decontamination Techniques. Journal of Contemporary Water Research \& Education. 2009;129:18-21.

28. Stafford T. Plastics in Pressure Pipes. Shewsberry, UK: iSmithers Rapra Publishing; 1998. $152 \mathrm{p}$.

29. Kelley KM, Stenson AC, Cooley R, Dey R, Whelton AJ. The cleaning method selected for new PEX pipe installation can affect short-term drinking water quality. Journal of Water and Health. 2015;13(4):960-9.

30. ASTM International. ASTM D543 - Standard Practices for Evaluating the Resistence of Plastics to Chemical Reagents. 2006. 1-7 p.

31. Zhang Y, Edwards M. Accelerated chloramine decay and microbial growth by nitrification in premise plumbing. Journal of the American Water Works Association. 2009;101(11):5162.

32. ASTM International. Standard Test Method for Compositional Analysis by Thermogravimetry. 2014;i:1-4.

33. Anderson JW, Neff JM, Cox BA, Tatem HE, Hightower GM. Characteristics of dispersions and water-soluble extracts of crude and refined oils and their toxicity to estuarine crustaceans and fish. Marine Biology. 1974;27(1):75-88.

34. Buchberger S, Omaghomi T, Wolfe T, Hewitt J, Cole D. Peak Water Demand Study: Probability Estimates for Efficient Fixtures in Single and Multi-family Residential Buildings. 2015. 68 p. Submitted to American Society of Plumbing Engineers. Rosemont, IL USA.

35. Stubbins A, Dittmar T. Low volume quantification of dissolved organic carbon and dissolved nitrogen. Limnology and Oceanography: Methods. 2012;10(5):347-352.

36. Pretzel CW. ES\&H Development Activities for the W89 Warhead. Albequerque, NM; 1995. $115 \mathrm{p}$.

37. Nishijima W, Okuda T, Nakai S, Okada M. A green procedure using ozone for Cleaning-inplace in the beverage industry. Chemosphere. 2014;105:106-11. 
38. ASTM International, Lampman S. Characterization and Failure Analysis of Plastics. ASTM International; 2003. 489 p.

39. Dasgupta A, Pecht M. Material failure mechanisms and damage models. IEEE Transactions on Reliability. 1991;40(5):531-536.

40. Dao KC. Mechanical properties of polypropylene/crosslinked rubber blends. Journal of Applied Polymer Science. 1982;27(12):4799-4806.

41. Salamone JC. Polymeric Materials Encyclopedia, Twelve Volume Set. CRC Press; 1996. $9600 \mathrm{p}$.

42. Stafford T. European Plastic Pipes Market. iSmithers Rapra Publishing; 2001. 141 p.

43. Levitan LC. Used Agricultural Plastics Sorted by Resin \& Typical Level of Contamination. 2014. Recycling Agricultural Plastics Program, Cornell University; Ithaca, NY USA.

44. Robertson GL. Food Packaging: Principles and Practice, Second Edition. Boca Raton, FL: CRC Press; 2005. 568 p.

45. American Water Works Service Company, Inc. Deteriorating Buried Infrastructure Management Challenges and Strategies. Voorhees, N.J; 2002. 37 p.

46. Whelton AJ, Dietrich AM, Gallagher DL. Contaminant Diffusion, Solubility, and Material Property Differences between HDPE and PEX Potable Water Pipes. Journal of Environmental Engineering. 2010;136(2):227-237.

47. Scheirs J. A Guide to Polymeric Geomembranes: A Practical Approach. John Wiley \& Sons; 2009. 596 p.

48. AWWA. 2007. Crosslinked polyethylene PEX pressure pipe, $1 / 2$ in $12 \mathrm{~mm}$ through 3 in. 76 $\mathrm{mm}$, for water service. C904-06, Denver, CO.

49. Hirose K, Harte BR, Giacin JR, Miltz J, Stine C. Sorption of d-Limonene by Sealant Films and Effect on Mechanical Properties. ACS Symposium Series. 1988.

50. Teuten EL, Saquing JM, Knappe DRU, Barlaz MA, Jonsson S, Björn A, Rowland SJ, Thompson RC, Galloway TS, Yamashita R, et al. Transport and release of chemicals from plastics to the environment and to wildlife. Philosophical transactions of the Royal Society of London. Series B, Biological sciences. 2009;364(1526):2027-45.

51. Wright DC. Failure of Polymer Products Due to Chemical Attack. iSmithers Rapra Publishing; 2001. 106 p.

52. ASTM International. ASTM D638-14 Standard Test Method for Tensile properties of plastics. 2014.

53. Zhao Q, Li X, Gao J. Aging behavior and mechanism of ethylene-propylene-diene monomer (EPDM) rubber in fluorescent UV/condensation weathering environment. Polymer Degradation and Stability. 2009;94(3):339-343.

54. Formela K, Sulkowski M, Saeb MR, Colom X, Haponiuk JT. Assessment of microstructure, physical and thermal properties of bitumen modified with LDPE/GTR/elastomer ternary blends. Construction and Building Materials. 2016;106:160-167.

55. Ferreira LM, Leal JP, Casimiro MH, Cruz C, Lancastre JJH, Falcão AN. Evidence of structural order recovery in LDPE based copolymers prepared by gamma irradiation. Radiation Physics and Chemistry. 2014;94:31-35.

56. Mohammadi R, Wassink J, Amirfazli A. Effect of surfactants on wetting of superhydrophobic surfaces. Langmuir. 2004;20(22):9657-62.

57. Tang J, Gallagher DL, Dietrich AM. Predicting Permeation of Organic Contaminants into Polyethylenes. Journal of Environmental Engineering. 2012;:120910004732003. 
58. Davis D. Spill Prevention, Preparedness, \& Response Program. 2011. http://www.ecy.wa.gov/programs/eap/qa/Agency/ECY_SPILLS_SOP_Collecting Oil Spill HCID Samples_v1.0SPL002.pdf

59. Hall J. Methods used by EPA to create crude oil contaminated drinking water for decontamination studies. (2016, February 11). Personal Communication. USEPA.

60. Agency for Toxic Substances and Disease Registry (ATSDR). Toxicological Profile for Benzene. U.S. Public Health Service, U.S. Department of Health and Human Services, Atlanta, GA. 2007.

61. Kelley KM, Stenson AC, Dey R, Whelton AJ. Release of drinking water contaminants and odor impacts caused by green building cross-linked polyethylene (PEX) plumbing systems. Water Research. 2014;67:19-32.

62. Ong SK, Gaunt JA, Mao F, Cheng C-L, Esteve-Agelet L, Hurburgh CR. Impact of Hydrocarbons on PE-PVC Pipe and Pipe Gaskets. American Water Works Association Research Foundation [now Water Research Foundation]. Denver, CO; 2008. 232 p. 